\title{
Preparation and Study Hardness and Thermal Conductivity (Tc) to Polyester Resin Composite with (Titanium Dioxide, Zinc Oxide, Acrylonitril, Wood Flour Coconut).
}

\author{
Tariek A. Al-Anie* Khalil Th. Hassan* Asmiet R. Al-Hadithy*
}

Received 1, March, 2009

Accepted 28, October, 2009

\begin{abstract}
:
This study is attempt to improve thermal isolation through measuring thermal conductivity composite of on polyester resin with fillers of $\left(\mathrm{TiO}_{2}, \mathrm{ZnO}\right.$, Acrylonitril, wood flour Coconut (Wf). The grain size of the fillers is $200 \mu \mathrm{m}$. The number of samples is (16) in addition to the virgin sample; these samples are prepared by cast molding method for polyester with filler volume fractions $(5 \%, 10 \%, 15 \%$ and $20 \%)$.

Shore hardness tests were used to measure the hardness and Lee disk method for thermal conductivity. The experimental results showed that the $(20 \% \mathrm{ZnO})$ sample has the maximum value of thermal conductivity where ( $20 \%$ w.f) has minimum thermal conductivity .on the other hand $(15 \% \mathrm{ZnO})$ sample give the maximum value of hardness where (20\% w.f) sample gave the minimum value of hardness. From this study there is an important factor that should be observed that is the relationship between hardness and thermal conductivity. The study prove that the experimental results satisfy the theoretical assumptions in that the additive material (fillers) of metals base increase thermal conductivity where the material of cellulose base decrease the thermal conductivity and give good thermal isolation but with low hardness and all the result above the refry sample .
\end{abstract}

Key words: Thermal conductivity, Polyester resin, Hardness, Thermal isolation, Wood flour coconut.

\section{Introduction:}

The progress of plastic technology lead to make polymers one of the competence materials in stead of steel, aluminum, wood \& other installation materials [1].Thus plastic $\&$ specially plastic composites became largely used instead of other materials in both aspects agricultural \& industrial [2].Thermal isolation formed one of the important reasons to keep energy expenses [3].Also to reduce required materials in heating \& cooling. The heat transfer through material achieved by impaction operation between molecules or atoms which formed the material, these phenomena is known as thermal conductivity. When direct touching of bodies [4]. According to this will transfer from hot side to cold side through material boundaries which isolated both sides. Thus chemical construction of molecules \& atoms act as an important rule to achieve heat transfer or isolating [5]. In this study we used certain polyester resin which can be classified as thermosetting plastic which is widely used in all life aspects such as high building, ships, boats \& others. Technical industries achieved very good results in reinforcement plastic especially with

*College of Science -Alanbar University 
fiber glass [6].On a form of composite or blend polymers vinyl monomers grafting with other polymers [7], or metal salts to produce composite laminate which was used in special kind of houses, storage tanks for oil or water [8] [9].

Use of Zinc oxides $(\mathrm{ZnO}) \&$ titanium oxides $\left(\mathrm{TiO}_{2}\right) \&$ other materials will give more hardness to composite so as to produce laminate or pieces of reinforced plastic [10]. Which can be resistance for mechanical actions \& can bear all other hard use conditions, but the existence of metals in the plastic body will indicate other factors of thermal or electrical conduction \& this due to the existence of transferred electrons through atoms orbital specially (d) orbital for transferred elements [11]. This will led the plastic reinforced by metals to have high thermal conductivity \& hardness than unreinforced plastic \& also we used mixing metal by adding vinyl monomer which contain unsaturated groups which is able to polymerized \& cross-link with resin [12], Which will increase hardness \& give glassy specifications.

Now wood flour plastic composites (WPC) is widely used by using of other soft powder mixed with polymers.

In this study wood flour coconut is used in form of soft powder to give good thermal isolation due to being isolated cellulose material [13].

One of the important studies in thermal conductivity field was achieved by the researchers ( Elsenbaumer and others) [14] on [PET,PC,PVC] polymers, the result insisted that crystalline polymers give thermal conductivity higher amorphous polymers. The Canadian research institution was able to produce plastic pipes made of certain low thermal conductive polymers [15][6]. On 2003 (J.C. Hassien) proved that thermal conductivity will increased with in the increase of solidification temperature \& they have leaner relation [17]. Where as (V. Flaingan \& his partner J.Z.Hu, 2005), found that thermal conductivity of polymer mixed with Soya bin Oil \& other physical properties will increase with the increasing of solidification temperature spatially when it being high, which will give exothermal reactions [18]. Same results was presented by Shabeer \& yadar[19] same as previous results.

\section{Materials and Methods:}

Unsaturated polyester used as a matrix material for fillers buy from Iraqi market (Jordan origin) has normal viscosity solute in styrene with percentage of $(38 \pm 1 \%)$.Cast molding used to product the samples by use of methyl ethyl ketone peroxides (MEKP) and cobalt actuate for solidification (BOH company), where the fillers $\left(\mathrm{TiO}_{2}, \mathrm{ZnO}\right.$ from Hupkon Com. , Acrylonitril from GGR Com. , Wood flour coconut from local market).

Mechanical mixer (Glekaup) kind U.K origin was used to mix filler with polyester in the 6 degree of speed (have 10 degree) for 5 minute, and then we add $1 \%$ of MEKP \& $0.1 \%$ of actuate. Table (1) illustrate preparation percentage of the samples .After mixing completed the mixture pot on centre fugue ( Heracuse Christ GMBH osterode Germany Origin) for two minute to remove Co babuls that created from reactions, then we cast the mixture inside the metal molds ( cylinder of $30 \mathrm{~mm}$ diameter \& $31 \mathrm{~mm}$ high ) after coated with thin player of paraffin .After leaving samples to solidification at room temperature for the next day, then remove the sample $\&$ pot in the oven (METLER kind Germany origin) for 90 minute to complete solidification. Fig (1) illustrates sample dimensions. 


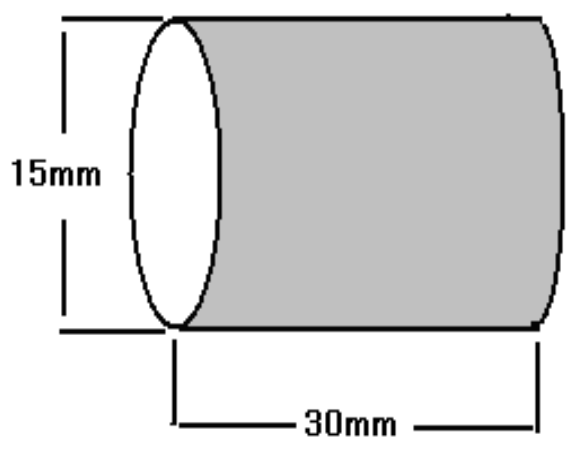

Fig. (1) Sample dimensions

Table(1) Composite Samples for this study.

\begin{tabular}{|c|c|c|c|}
\hline NO. & $\%$ Composite & NO. & $\%$ Composite \\
\hline 1 & Virgin UPE (only) & 10 & $5 \%$ Tio2 + UPE \\
\hline 2 & $5 \%$ ACN + UPE & 11 & $10 \%$ Tio2 + UPE \\
\hline 3 & $10 \%$ ACN + UPE & 12 & $15 \%$ Tio2 + UPE \\
\hline 4 & $15 \%$ ACN + UPE & 13 & $20 \%$ Tio2 + UPE \\
\hline 5 & $20 \%$ ACN + UPE & 14 & $5 \%$ ZnO + UPE \\
\hline 6 & $5 \%$ W.F. coconut + UPE & 15 & $10 \% \mathrm{ZnO}+$ UPE \\
\hline 7 & $10 \%$ W.F. coconut + UPE & 16 & $15 \% \mathrm{ZnO}+$ UPE \\
\hline 8 & $15 \%$ W.F. coconut + UPE & 17 & $20 \% \mathrm{ZnO}+$ UPE \\
\hline 9 & $20 \%$ W.F. coconut + UPE & & \\
\hline
\end{tabular}

Thermal conductivity test :-

Thermal conductivity measurement done by uses this equation:

$$
K=\frac{\text { Q.L }}{\operatorname{Ac}(\Delta T)}
$$

Where Q: quantity of heat (watt)

L: thickness of sample

Ac: area of specimen

$\mathrm{K}$ : conductivity

The kind of thermal equipment is (limited Arm field) U.K origin thermal conductivity get by take the change in temperature $\Delta \mathrm{T}$ between cold temperature(Tcold) \& heat temperature (Thot)

$$
\Delta \mathrm{T}=\mathrm{Th}-\mathrm{Tc}
$$

Hardness test:-

Shore test used to determined hardness of the samples by using (shore Durometer type D model THZ10, Italy origin) hardness test depend on the penetration of the needle on the spacemen surface.

\section{Results and Discussion:}

Heat transmit through plastic occur due to found crystalline spot or groups added to transfer the heat as in case of electrons in electrical conduction .The presence of impurities, salts and groups form canals that make plastics conduct or transmit heat . Plastic essentially isolated materials because of its chemical structure so that foams is bad heat conductive because it hasn't crystalline spot .The fillers (fiber, metal salts \&metal in form of powder) have important role in heat conductivity [20].

So it's important to product composite materials have high hardness with high thermal isolation [21].

In this study the filler material have grain size (200) $\mu \mathrm{m}$. Table (2) illustrate hardness values for the samples take by shore test. There is relationship between hardness \& thermal conductivity .The virgin sample give the lowest hardness (77.12), this identical with the theoretical idea in that the polymer has weak hardness and ability to fracture. Hence the maximum hardness value(91.05) gets by the sample $(15 \%$ $\mathrm{ZnO}$ ). This is because the $\mathrm{ZnO}$ fillers that contain $\mathrm{Zn}$ element how has an ability to make coordinated bonds with

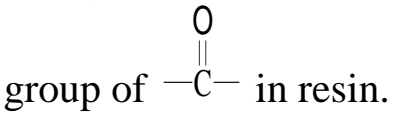<smiles></smiles> 
Where $\mathrm{Zn}$ can receive electrons couple that found in Oxygen atom to make metallic bond (coordinate) and increase cross-links to give high hardness. Titanium Oxide who has Ti element gives good hardness, hardness value increase with increasing volume fraction of $\mathrm{TiO}_{2}$.Sample No.13 $\left(20 \% \mathrm{TiO}_{2}\right)$ gives $(90.5)$ hardness, this also because that the Titanium ability to make coordinate metallic bonds (bridges), also it have sufficient surface area help to make good adhesive with polymers that increase hardness. The lowest value (78.6) is to sample No.8 (20\% W.F) composite, hence unsaturated Acrylonitril vinyl monomer gives medium hardness value that is because of its ability to cross-linked with the unsaturated resin.

Thermal conductivity value of samples study by use heat exchanged equipment that makes heat transmit through the body of sample under investigation. Heat transfer by contact between two sides of disk. The values obtained from this study give good indications about the nature of fillers material that added to polymers. Maximum value of thermal conductivity of composites is 15.245 $\mathrm{w} / \mathrm{mc}^{\circ} \quad(20 \% \mathrm{ZnO})$. This is from metallic properties of Oxides \& its ability to conductive heat. As we say already its ability to product coordinate bonds that make filling and structure of composite free volume that help to increase conductive. Minimum value of thermal conductivity is $8.064 \mathrm{w} / \mathrm{mc}^{\circ}$ $(20 \%$ W.F.) because the powder particles are cellulose origin that has bad thermal conductive, also it has alkynes in form of Lingo cellulose these material is bad thermal conductive, also it hasn't ability to make cross link with polymer chains, that generate vacancies from insert Wood flour Coconut powder inside resin, these vacancies impediment thermal Conductive.

Acrylonitril composite has thermal conductivity higher than titanium composites this because the unsaturated monomers $(\mathrm{C}=\mathrm{C})$ react with resin that also have unsaturated bonds $(\mathrm{C}=\mathrm{C})$ make cross-links, these cross links help to heat transmit through atoms in covalent bonds. We expect that $\mathrm{TiO}_{2}$ have ability to produce a tunnels or paths. This property found in element who have an absorpant surface, Titanium is one of them .

The study of thermal conductivity and hardness maintaining the concentration constant and changing the kind of the filler as showing in figure (10). The sequence of hardness is :

$\mathrm{ZnO}>\mathrm{W} . \mathrm{F}>\mathrm{AcN}>\mathrm{TiO}_{2}>$ Virgin

Hardness decrease

While the sample $10 \%$ represented in fig. (11) the order of hardness is:

$\mathrm{ZnO}>\mathrm{TiO}_{2}>$ W.F $>$ AcN $>$ Virgin

Hardness decrease

The specimen of $15 \%$ as fig (12) indicates that:

$\mathrm{ZnO}>\mathrm{TiO}_{2}>\mathrm{AcN}>$ W.F $>$ Virgin

Hardness decrease

The highest $20 \%$ graphed in fig. (13) the following result obtained :

$\mathrm{TiO}_{2}>\mathrm{ZnO}>\mathrm{AcN}>$ W.F $>$ Virgin

Hardness decrease

Hardness values give the impression that showed the highest value of hardness except that of $20 \% \quad \mathrm{TiO}_{2}$ which its hardness near to that of $\mathrm{ZnO}$. The reason of such behavior may be attributed to fact that zinc as transitional element coordinates with the active groups of resin, leading to sectional Cross-linkage. The specimen 
of $20 \%$ Tio2 is harder than of $\mathrm{ZnO}$ due to the formation of secondary forces(coordination).

At high percentages of Titanium would culminate Zinc which considered more metallic than $\mathrm{TiO}_{2}$ lead to high surface area of Titanium in the Zinc hardness. In the case of W.F 5\% gave good results of hardness due to that the low percentage made the Cross -linking more probable to certain extent on the other side increasing the percentage lead to hardness decrease, which may be because of increase in the Free volume.

It has been found that $\mathrm{AcN}$ gave better hardness than virgin and wood flour at high percents due to $\mathrm{AcN}$ has the cross-linking ability as acrylic monomer having double bond.

Thermal conductivity study which dealt with constant concentration and variable filler. Indicated that the $15 \%$ as the graphed in fig(14) is as following.

$\mathrm{ZnO}>\mathrm{AcN}>$ Virgin $>$ W.F $>\mathrm{TiO}_{2}$

Thermal conductivity decrease

While the $10 \%$ drawn in fig(15) led to: $\mathrm{ZnO}>\mathrm{AcN}>$ Virgin $>\mathrm{TiO}_{2}>$ W.F

Thermal conductivity decrease

Fig (16) $15 \%$ indicate as:

$\mathrm{ZnO}>\mathrm{AcN}>\mathrm{TiO}_{2}>$ Virgin $>$ W.F

Thermal conductivity decrease

The highest of $20 \%$ gave that:

$\mathrm{ZnO}>\mathrm{AcN}>\mathrm{TiO}_{2}>$ Virgin $>$ W.F

Thermal conductivity decrease

The result of thermal conductivity study are is a good agreement with the theoretical explanation which reveal that the addition of metals increase the T.C besides the $\pi$-bonds increment. This fact has been verified by the coconut wood flour specimens which gave lowest T.C , as well known that wood is bad thermal conductivity.

On the other hand in the case of $\mathrm{AcN}$, the strong cross-linking of the double bond and the other more stronger groups decrease the spaces and increase the crosslink, thus the heat transfer is more rapid due to the freevolume diminishing.

The cheated specimens with Tio2 gave higher T.C values at the percentage of $(15 \%, 20 \%)$ while at the lower percentage the reference T.C was higher than of $\mathrm{TiO}_{2}$ this could explained that at higher percentage the surface area is large which lead to higher adsorption on Titanium surface ,forming assort of chemo-physical linkage between the resin and the Titanium surface corresponding in higher T.C.

The lower percentage ( $5 \%$ and $10 \%$ ) of $\mathrm{TiO}_{2}$ couldn't afford the sufficient surface area in order to make Titanium dominates $\mathrm{AcN}$, thus $\mathrm{AcN}$ has higher T.C than $\mathrm{TiO}_{2}$ due to the cross-linking moreover the Titanium surface contains tunnel and gaps crippling the heat transfer.

\section{Conclusions:}

We can produce a composite hard, strong and thermal isolator by use low volume fraction of metallic fillers.

Use material have cellulose give composite of bad thermal conductivity.

There is proportional relation between hardness and thermal conductivity most study before production composite materials

Table (2) Hardness value by shore test.

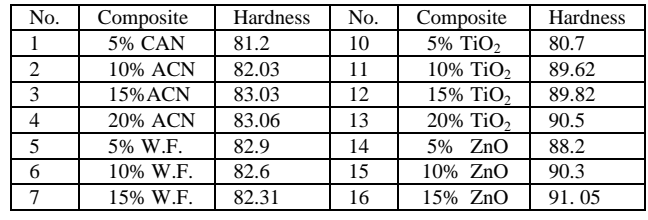




\begin{tabular}{|c|c|c|c|c|c|}
\hline \multirow{2}{*}{\multicolumn{6}{|c|}{ 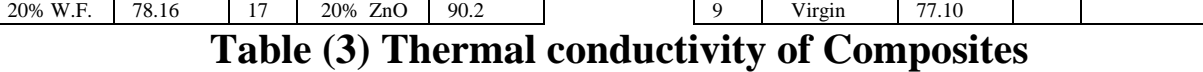 }} \\
\hline & & & & & \\
\hline No. & Composite & $\begin{array}{c}\text { Thermal } \\
\text { conductivity }\left(\mathrm{w} / \mathrm{mc}^{\circ}\right)\end{array}$ & No. & Composite & $\begin{array}{c}\text { Thermal } \\
\text { conductivity }\left(\mathrm{w} / \mathrm{mc}^{\circ}\right)\end{array}$ \\
\hline 1 & $5 \% \mathrm{CAN}$ & 12.7276 & 10 & $5 \% \mathrm{TiO}_{2}$ & 10.248 \\
\hline 2 & $10 \% \mathrm{CAN}$ & 12.663 & 11 & $10 \% \mathrm{TiO}_{2}$ & 10.631 \\
\hline 3 & $15 \% \mathrm{ACN}$ & 13.0138 & 12 & $15 \% \mathrm{TiO}_{2}$ & 11.2821 \\
\hline 4 & $20 \% \mathrm{CAN}$ & 13.1883 & 13 & $20 \% \mathrm{TiO}_{2}$ & 12.571 \\
\hline 5 & $5 \%$ W.F. & 10.585 & 14 & $5 \% \quad \mathrm{ZnO}$ & 12.7947 \\
\hline 6 & $10 \%$ W.F. & 9.9898 & 15 & $10 \% \mathrm{ZnO}$ & 14.12 \\
\hline 7 & $15 \%$ W.F. & 8.5221 & 16 & $15 \% \mathrm{ZnO}$ & 14.8777 \\
\hline 8 & $20 \%$ W.F. & 8.064 & 17 & $20 \% \mathrm{ZnO}$ & 15.2541 \\
\hline 9 & Virgin & 11.2521 & & & \\
\hline
\end{tabular}

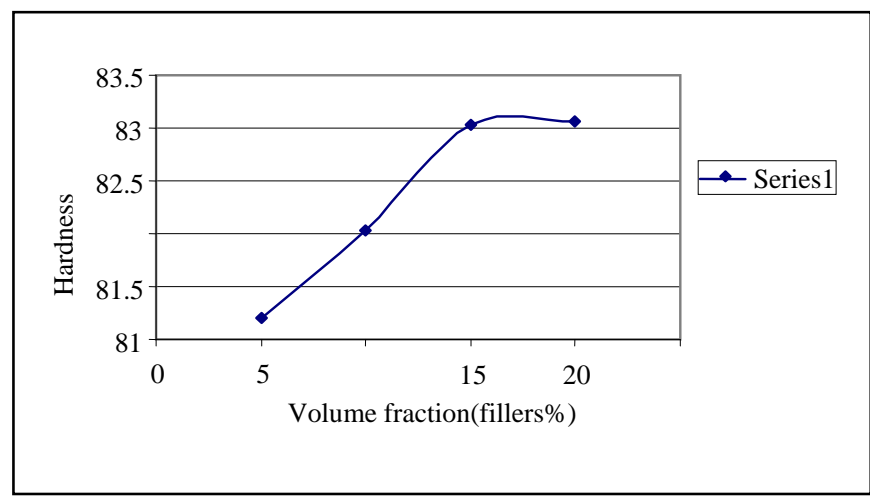

Fig (2): Shore hardness test for ACN Composite

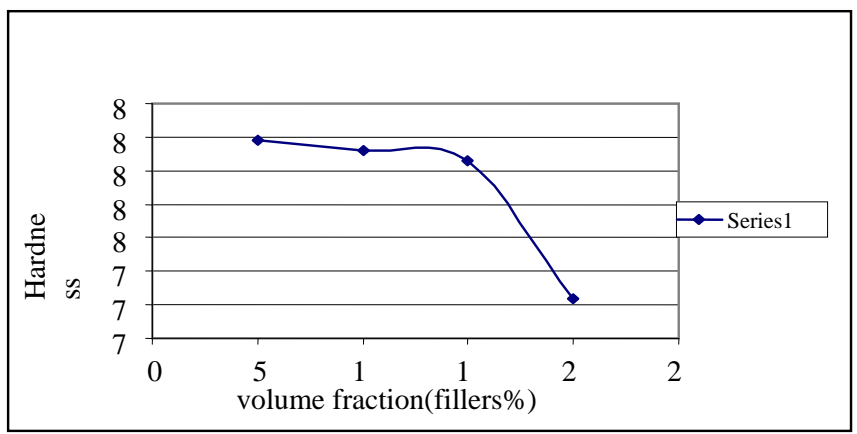

Fig (3): Shore hardness test of W. F. coconut Composites

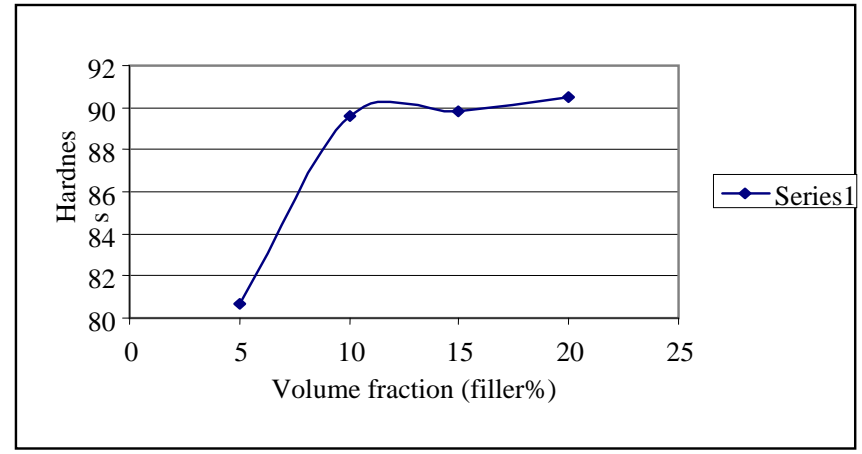

Fig (4): Shore hardness test of $\mathrm{TiO} 2$ Composites 


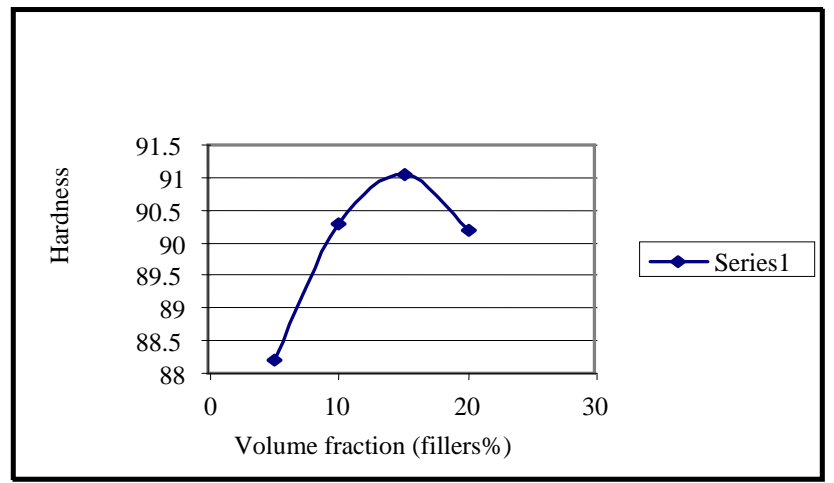

Fig (5): Share hardness test for ZnO Composites

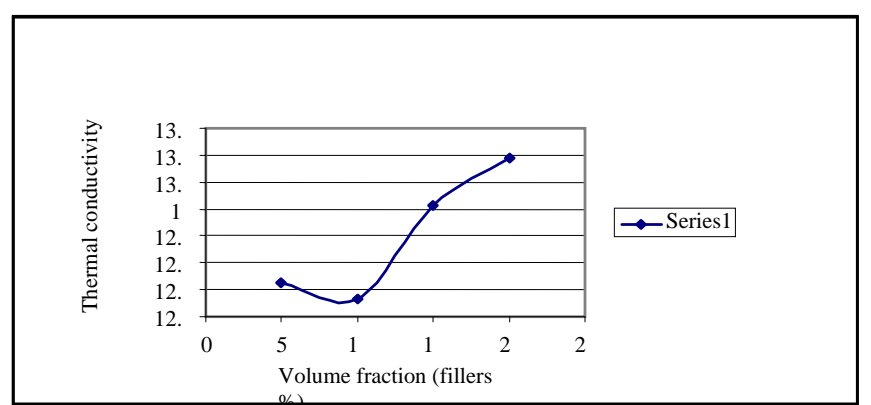

Fig (6): Thermal Conductivity Test of ACN Composites

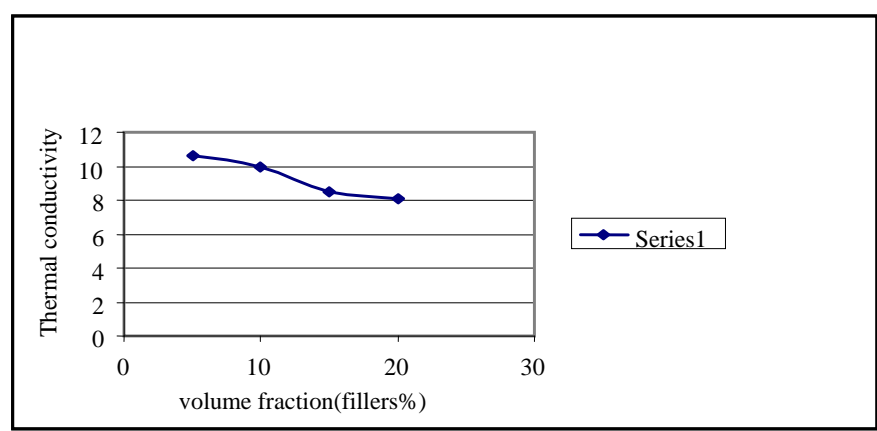

Fig (7): Thermal Conductivity test of W.F.coconut Composites

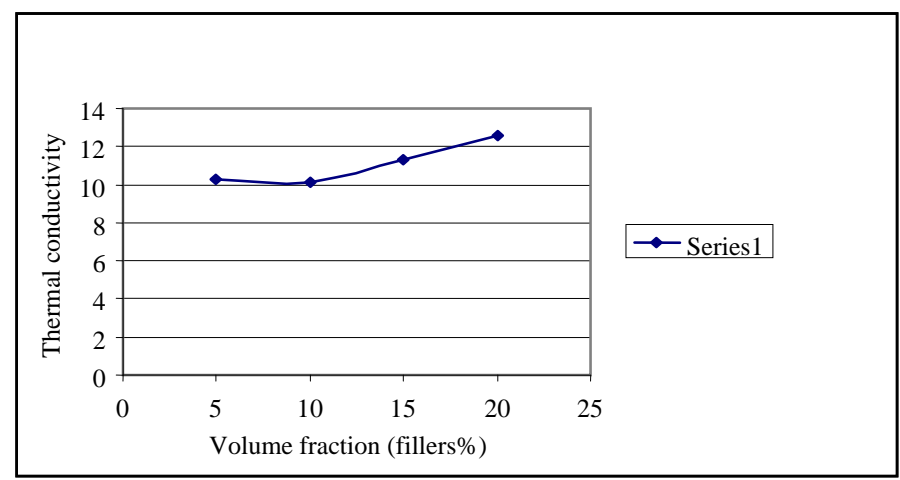

Fig (8): Thermal conductivity test of $\mathrm{TiO} 2$ Composite 


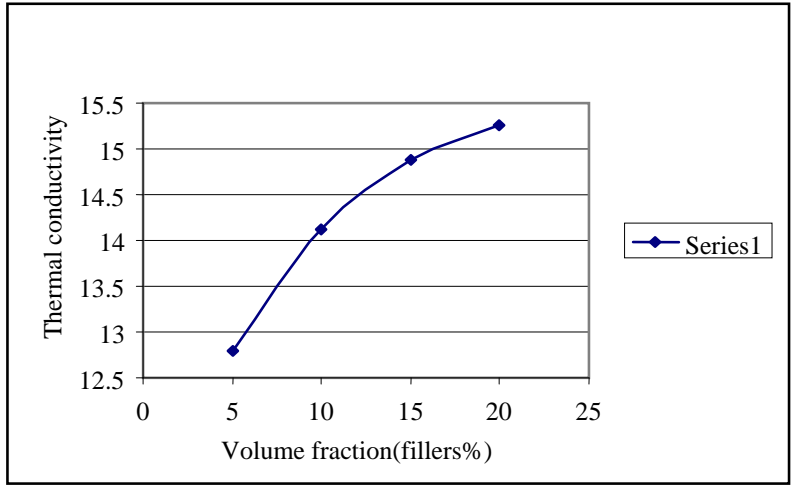

Fig (9): Thermal conductivity test of $\mathrm{ZnO}$ Composites
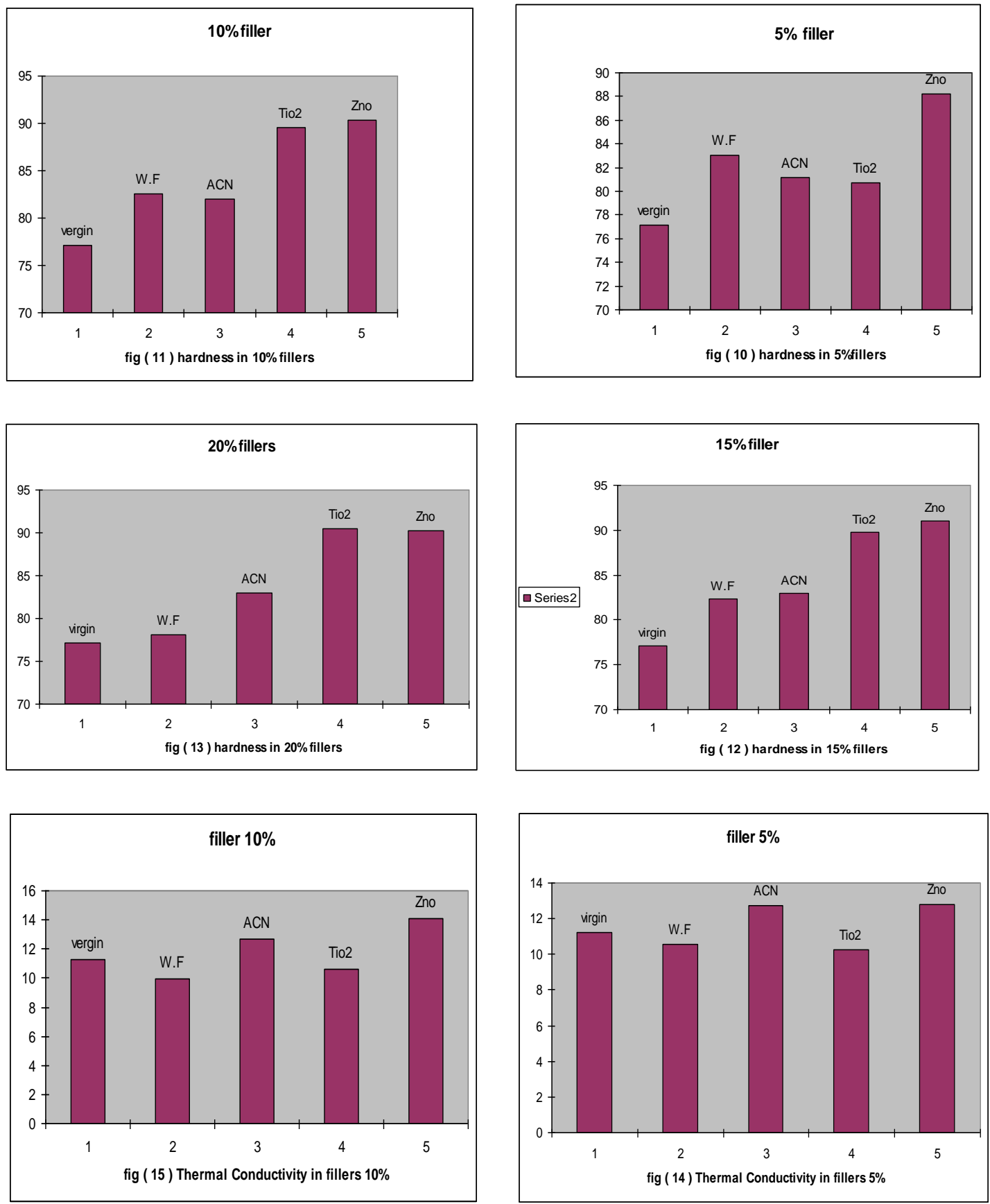


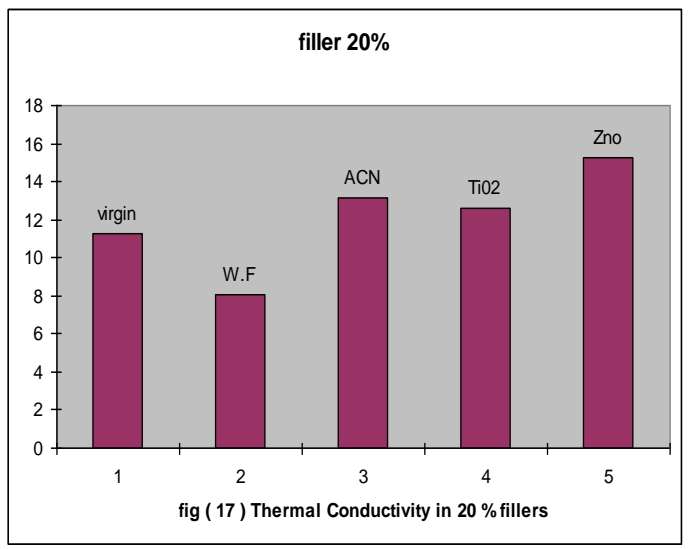

\section{References:}

1-Frank. $\mathrm{H}$ and Meyer. Y. 1992 Predicting the tensile strength behavior of product glass reinforced polymer, J. Material, Sci, 27:280-287.

2- Kuleznev N.V. 1982 Polymer blend khimia Moscow.chap.2,.

3- Bueche.F and jerde.D. 1995 "Principle of physics " $1^{\text {st }}$ ed, Graw-Hill p (411),.

4- Corbier-Nicollier and Laban. L 2003 Life cycle assessment of biological fiber recourses, conserving and recycling, 33(4) :22-27.

5- Boeing. H.V. 1964. Unsaturated polyester structure $\&$ properties. $1^{\text {st }}$ ed, Elsevier, New York.

6-Weitsman.1996. Effect of fluid on polymeric composite, Naval Research, No- n0014-90-J1556July.

7- May. C.A. 1993 Pure, Apply. Chem. Issue. 811..

8- Pothan. L.A. and Sabu. N. T. 1997. Short fiber reinforced composite, Jreinforced plastic and composite (18):744-765,.

9-Meizhany, P.Ramon. 2004 Nattered latters, 58 (3-4) : 408-412.

10 - Thams. H , Epply. $M$ and Roller.A. 1997. Solid state ionic, 101-103,79-89,

11- Miyake. H and Tsuchida.T.1987. USA patent (4016115)Unsaturated polyester copositon.

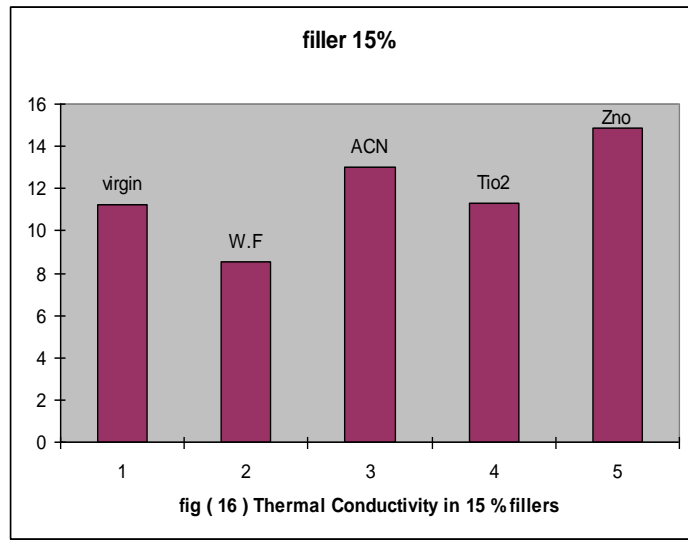

12- Wood. D.P. 2001 The chemical physics of solid surface, volume 9 , Elsevier Armstrong.

13. Wallen Berger. F.J. and Weston .N. 2001 Nature fiber, Plastic composite Nature material scence Book from C.H.I.P.S Texas.

14- Elsenbaumer. R, Delannoy and P, Miller. G. 1985. Thermal enhancement of electrical conductivities of alkali metaldoped of polyacetylene complexes, Synthetic Metals, 11(4-5) : 251270.

15- Natural research council Canada A.1982. Blaga (Canadian building) digests.

16- Joeler.F. 2005 Polymer Science and Technology, Chap(2), P(54), Prentic Hall.

17- Hassien. J.C , Pusateiogla S.Y., Frieke. A.1. 2003 Journal of Applied polymer Science. 24(4) : 947-952.

18- Zhu.J. Flauigan.V and Kapila S. 2003. Applied science manufacturing, part A, 35:95-101.

19- Yadar R. and Shabeer. A. 2006. Center to Environmental science \&technology proceeding of the samples conference, long beach (A), pp1-10,

20- Scott. W and Lai. J. 1995. Mechanical behavior of Fiber reinforced Plastic \& Composite, 14 (5) : (588-617). 
21- Dhakate. S.R, Sharma. S and for PEM fuel cell" International Borah. M, 2008" Expanded graphite-based electically Journal of Hydrogen energy" conductive composite bipolar plate

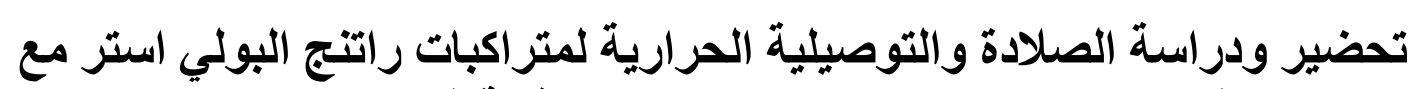

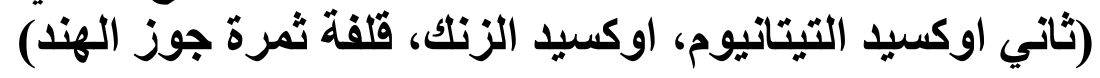

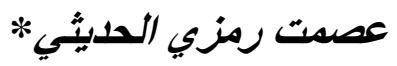

*ليل ثابث حسان
طارق عبل الجبليل العانسي*

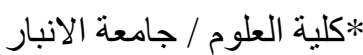

تمت في هذه الدراسة محاولة تحسين العزل الحراري من خلال قياس التوصيل الحراري لمتر اكبات

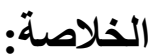

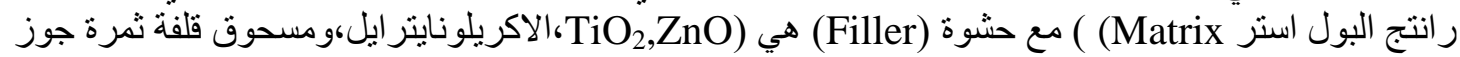

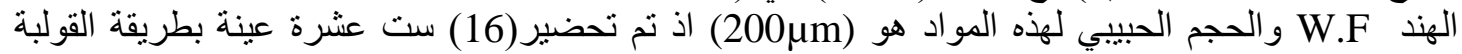

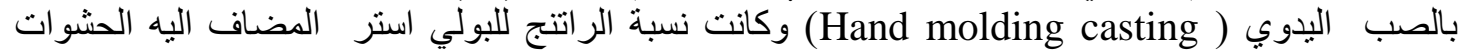

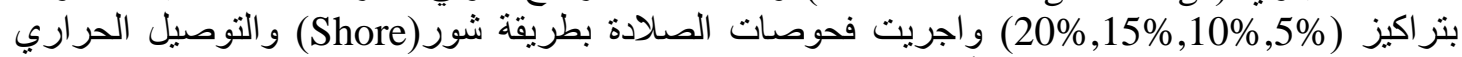

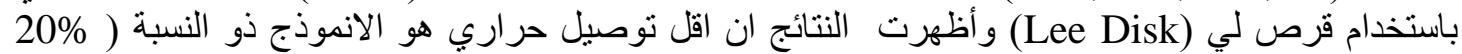
وان أعلى توصيل حراري هو الانموذج ذو النسبة(W.F coconut

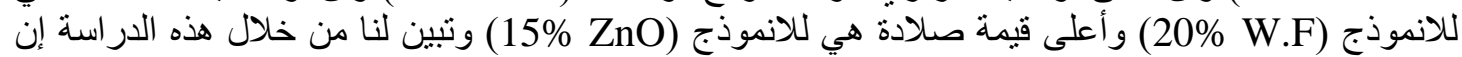

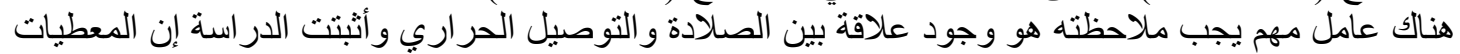

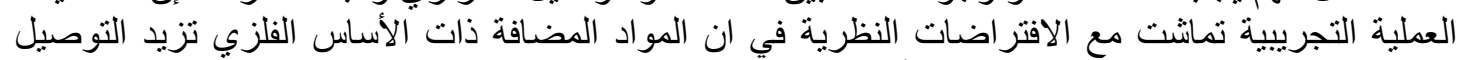

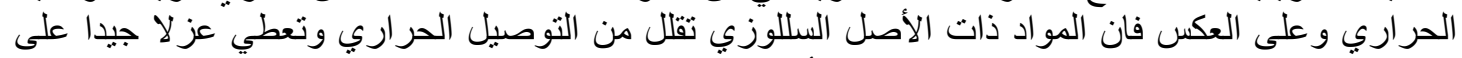

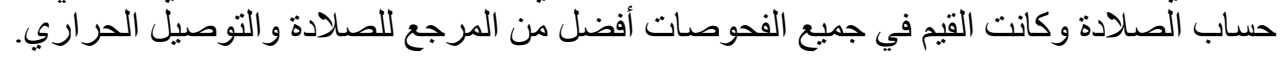

